\title{
NORTH VENTURA AVENUE AREA PLAN (DRAFT UPDATE)
}

\author{
A Professional Project \\ presented to \\ the Faculty of California Polytechnic State University, \\ San Lus Obispo
}

In Partial Fulfillment

of the Requirements for the Degree

Master of City and Regional Planning

by

Rick A. Casswell

June 2009 
(C) 2009

Rick A. Casswell

ALL RIGHTS RESERVED

COMMITTEE MEMBERSHIP 
TITLE:

AUTHOR:

DATE SUBMITTED:

COMMITTEE CHAIR:

COMMITTEE MEMBER:

COMMITTEE CHAIR:

COMMITTEE MEMBER:
North Ventura Avenue Area Plan (Draft Update)

Rick A. Casswell

June 2009

Paul Wack (Professor, City and Regional Planning)

Zeljka Howard (Lecturer, City and Regional Planning)

Bruce Smith (General Plan Supervisor, Ventura County

Planning Division) 


\section{ABSTRACT \\ North Ventura Avenue Area Plan (Draft Update)}

Rick A. Casswell

This professional project provides a much needed draft update to the existing Area Plan for North Ventura Avenue (last amended in 1990), an unincorporated area of the County that falls under the City of Ventura's sphere of influence. New goals, policies and programs have been provided to supplement the goals, policies and programs of the current countywide General Plan for Ventura County (adopted in 2005). The supplemental goals, policies and programs proposed in this draft update apply specifically to North Ventura Avenue, and account for a pending annexation of the area by the City of Ventura.

The overall aim of this project was to provide the Ventura County Planning Division with a draft update to the existing North Ventura Avenue Area Plan that reflects modern planning practice and theory. Sustainable growth and development for the area are the underlying goals of this proposed draft update. Reducing auto-dependency through the proposed adoption of a 'mixed-use specific plan' land use category represents the most pertinent recommendation of this draft update in aiming to achieve sustainable growth and development of the area in the future. 


\section{ACKNOWLEDGEMENTS}

I would like to thank all of my committee members for their support, wisdom, and generosity of time throughout my project. Without them my project would not have been possible.

In addition, I would like to thank the GIS staff at Ventura County's Planning Division for working so efficiently and obligingly at such short notice. The maps that they have helped me produce are an integral component of this project.

Finally, I would also like to thank my family for supporting me throughout graduate school, and for helping me get through my final weeks of school! 


\section{Ventura County General Plan}

\section{NORTH VENTURA AVENUE AREA PLAN (DRAFT UPDATE)}

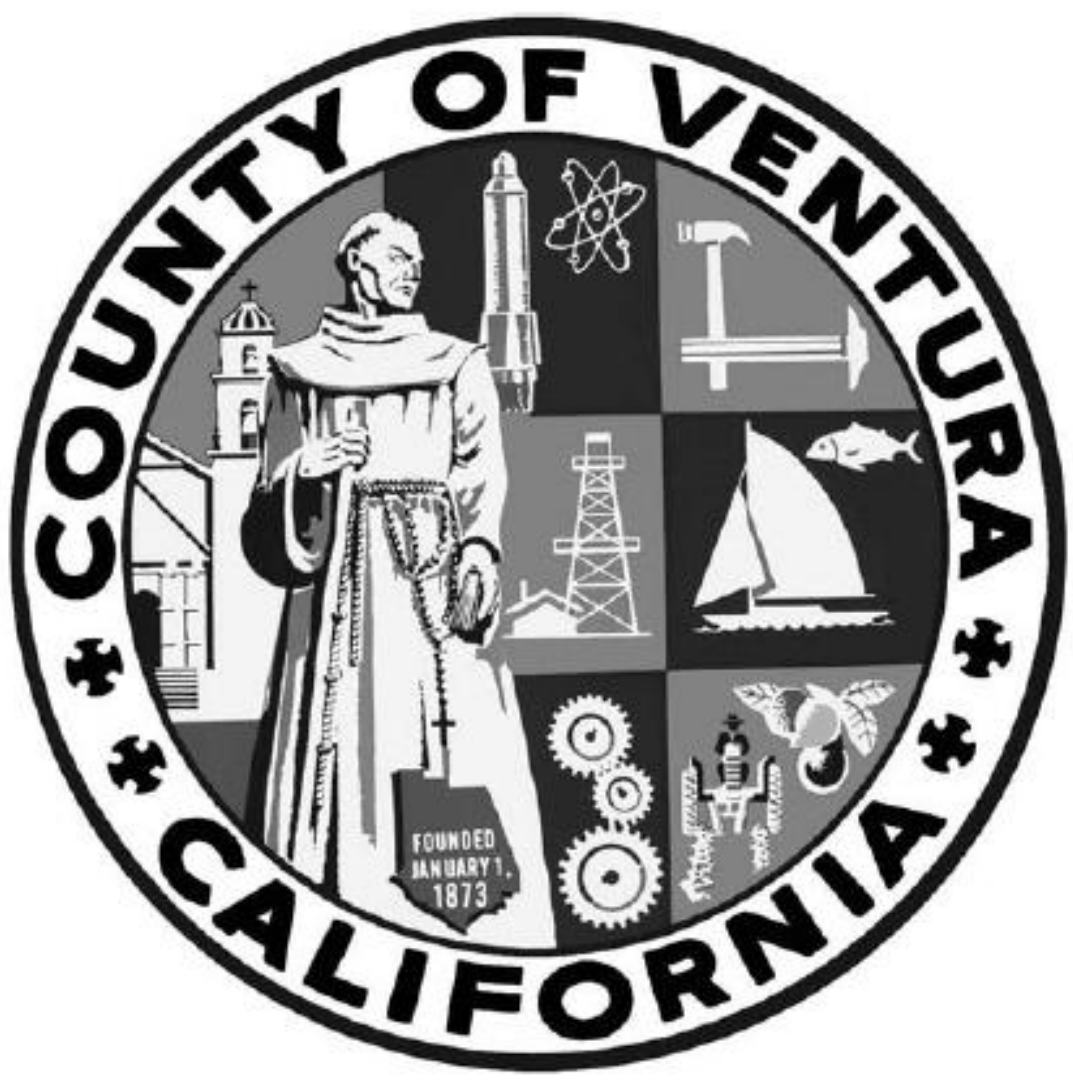

Last Amended 12-11-90 Ventura County Planning Division

Draft Update 06-09-09 


\section{Table of Contents}

Introduction

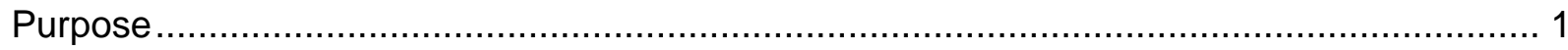

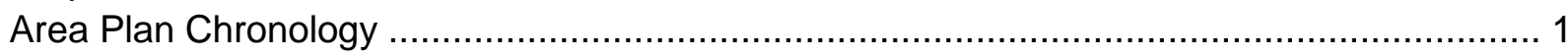

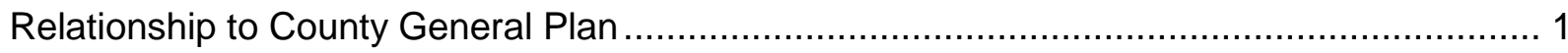

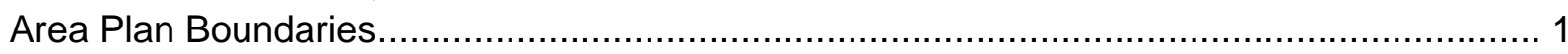

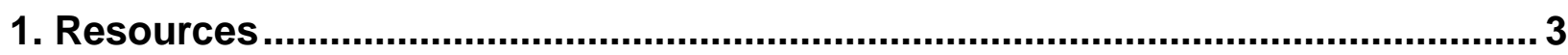

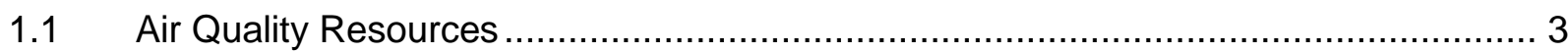

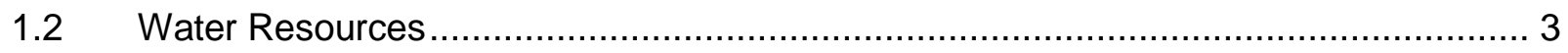

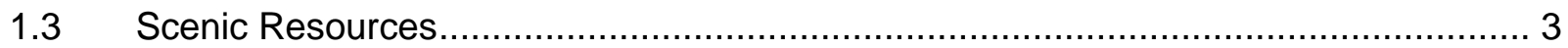

1.4 Energy Resources .................................................................................... 3

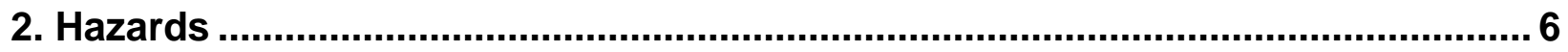

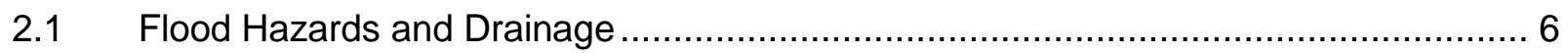

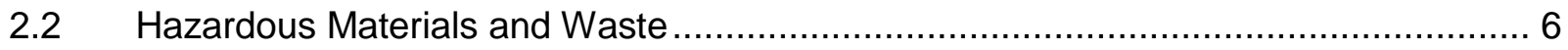

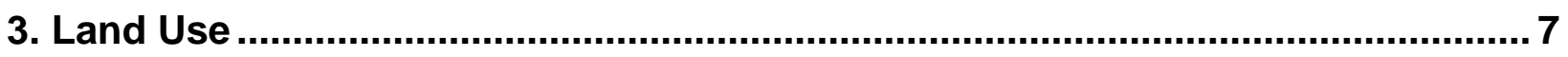

3.1 General Goals, Policies and Programs .............................................................. 7

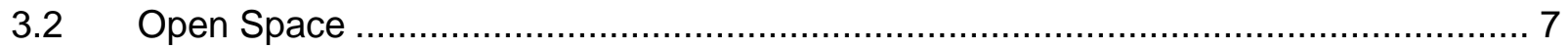

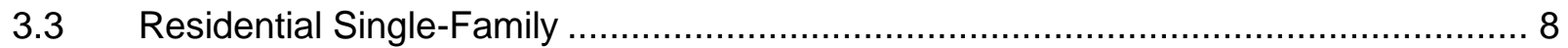

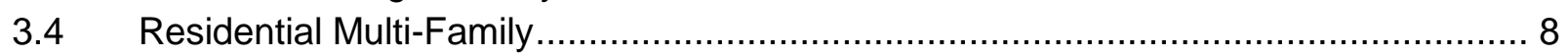

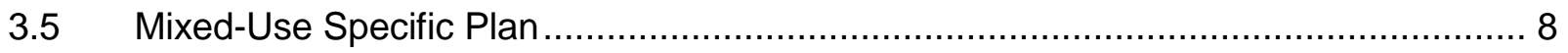

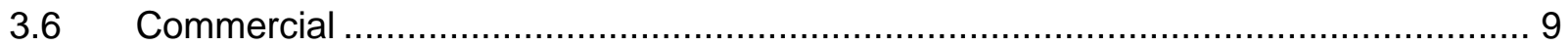

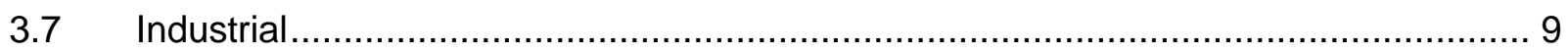

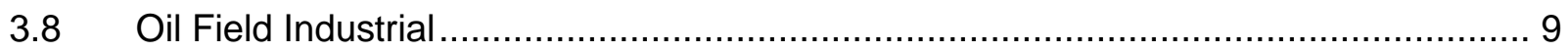

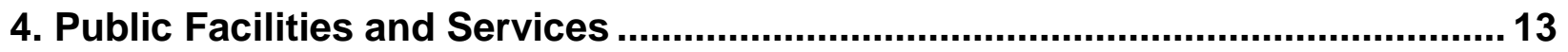

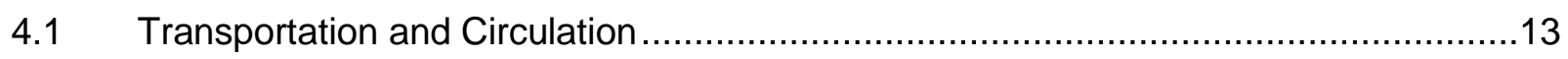

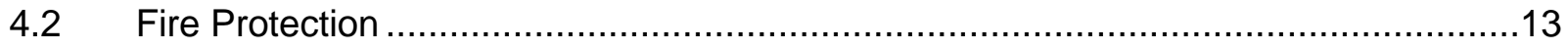

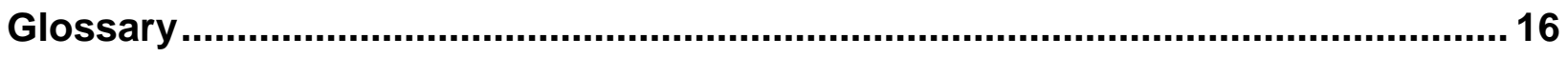

\section{List of Figures}

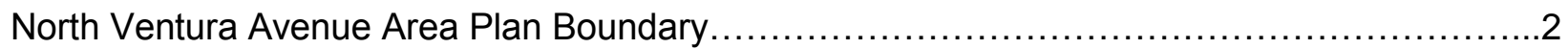

Figure 1 North Ventura Avenue Scenic Resource Area.............................................

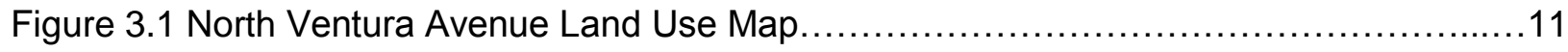

Figure 3.2 North Ventura Avenue Zoning Compatibility Matrix....................................12

Figure 3.3 Summary Table - Building Intensity/Population Density Standards...................13

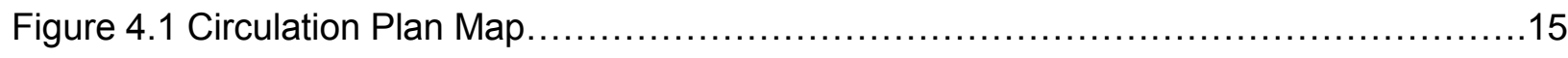

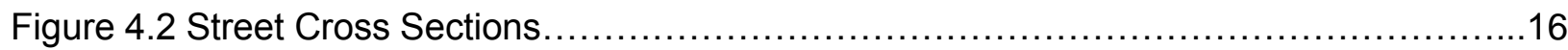




\section{Introduction}

This document is an Area Plan for the North Ventura Avenue area (an unincorporated community). It is the intent of this document to provide a plan which will clearly state the County's land use policies, and provide a basis for future land use decision-making in the area.

\section{Purpose}

The purpose of this Area Plan is to set goals, policies and programs which supplement those set forth in the County's General Plan Goals, Policies and Programs in guiding future growth and development for the North Ventura Avenue area. The supplementing goals, policies and programs have considered the vision, goals and recommended actions set forth in the City of Ventura's General Plan to facilitate the City's anticipated annexation of North Ventura Avenue.

\section{Area Plan Chronology}

In 1968, the City and County adopted the Ventura Avenue Plan, which included the North Ventura Avenue area. In late 1981, the City's Sphere of Influence was defined by the Local Agency Formation Commission as including the North Ventura Avenue area. Inclusion on the sphere indicated that the area should eventually be annexed into the City, and the decision was made to evaluate and update land use and public service policies for the area. After a series of public hearings, the City of San Buenaventura City Council adopted the Comprehensive Plan Amendment for the North Avenue on December 13, 1982 and certified the North Avenue Plan EIR. During the preparation of the Plan it became evident that the annexation of the area to the City would proceed slowly and that most development would occur under County jurisdiction.

Following the City Council's action, County and City staff prepared the North Ventura Avenue Area Plan, based on the City's Plan, which was adopted by the Ventura County Board of Supervisors on April 17, 1984. Amendments have since been made to this Area Plan on May 24, 1988; December 19, 1989; and December 11, 1990.

Based on the City's recent intent to move forward with the annexation of North Ventura Avenue, and a new format for County Area Plans, this draft update to the North Ventura Avenue Area Plan provides the County with a Plan that is more reflective of the present day planning approaches and current City vision for the area.

\section{Relationship to County General Plan}

The Ventura County General Plan is the Plan by which the unincorporated portions of Ventura County will develop in the future. The Ventura County General Plan consists of: (a) Countrywide Goals, Policies, and Programs document containing four chapters (Resources, Hazards, Land Use, and Public Facilities and Services); (b) four appendices (Resources, Hazards, Land Use, and Public Facilities and Services) which contain background information and data in support of the Countrywide Goals, Policies and Programs; and (c) several area plans which contain specific goals, policies, and programs for specific geographic areas of the County. This North Ventura Avenue Plan is the Area Plan for the North Ventura Avenue Area of Interest.

\section{Area Plan Boundaries}

The North Ventura Avenue area is bounded to the north by the Ojai Valley Area Plan boundary, and extends south to the Ventura city limits, encompassing all unincorporated parcels along Ventura Avenue and contained within the highest ridgeline boundaries to the east and west, extending north to the Ojai Valley Area Plan boundary. The east and west boundaries have been determined as the highest ridgelines visible from Highway 33, between the Ventura city limits and the Ojai Valley Area Plan boundary to include the Scenic Resource Protection (SRP) zone. 


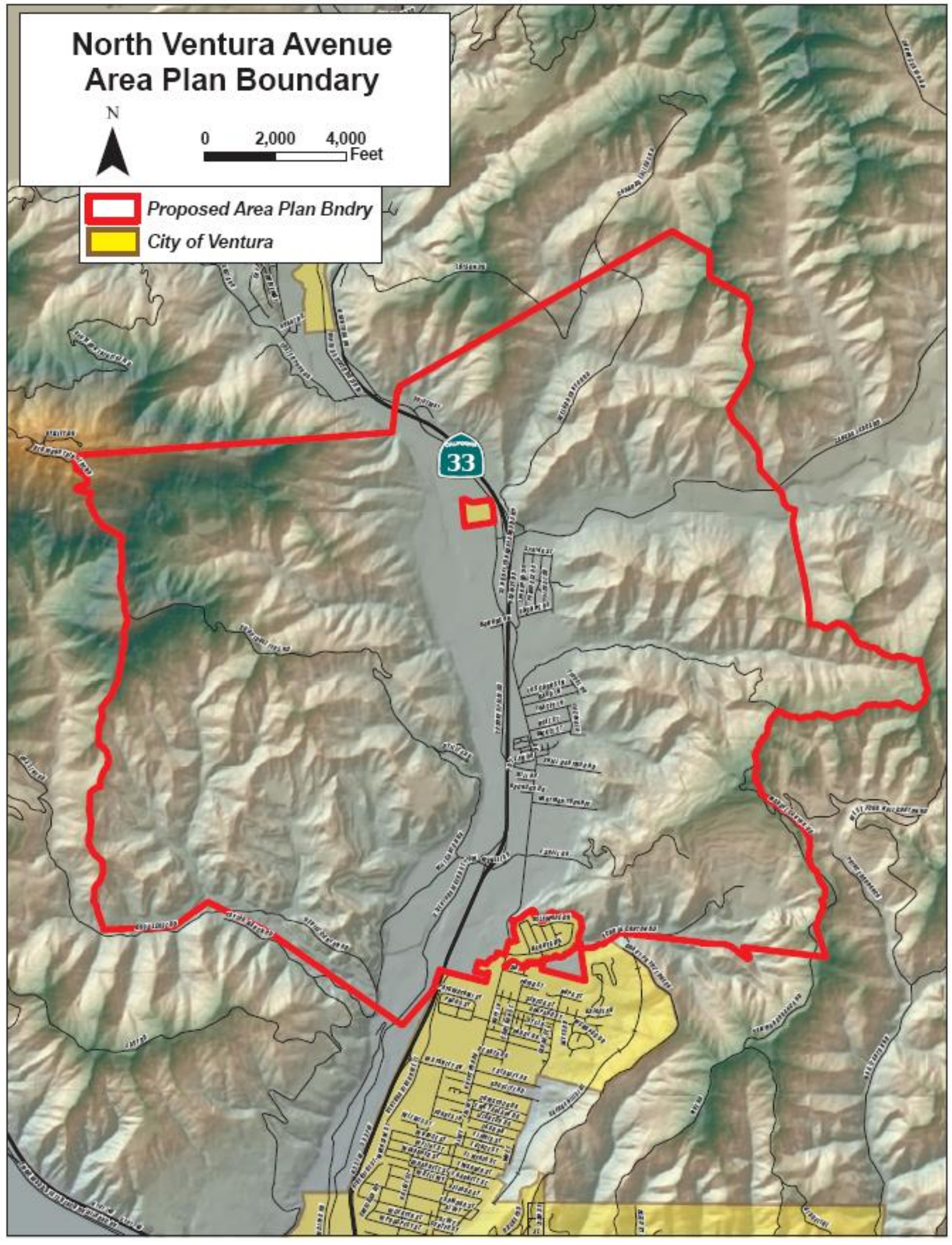




\section{Resources}

Goals, policies, and programs of the countywide Goals, Policies and Programs will continue to be applied to the North Ventura Avenue area and are supplemented by the following goals, policies:

\subsection{Air Quality Resources}

\subsubsection{Goal:}

Reduce air quality impacts and global climate change of development by reducing reliance on motor vehicle travel and supporting energy efficient land use.

\subsubsection{Policies:}

(See Sections 3.1.2 and 3.6.2 of the Land Use chapter, and Section 4.1.2 of the Public Facilities and Services chapter)

\subsubsection{Programs:}

(See Sections 3.1.3 and 3.6.3 of the Land Use chapter, and Section 4.1.3 of the Public Facilities and Services chapter)

\subsection{Water Resources}

\subsubsection{Goal:}

Reduce water demand by improving water conservation.

\subsubsection{Policy:}

All discretionary development shall use native, drought-tolerant vegetation for at least 50 percent of site landscaping.

\subsection{Scenic Resources}

\subsubsection{Goals:}

1. Protect and remediate the view of hillsides as seen from Highway 33.

2. Ensure that oilfield industrial activity along hillsides, as seen from Highway 33 , does not starkly contrast in appearance to the hillside's natural state.

3. Protect the City of Ventura's Scenic Approach through the Scenic Resource Protection overlay zone.

\subsubsection{Policies:}

1. No discretionary development shall significantly adversely affect the view of the slopes to the highest major ridgeline as seen from Highway 33.

2. All discretionary development for hillside oil activity shall require oil dereks to be painted dark green as a way of blending these structures into their natural surroundings.

3. Land designated Scenic Resource Area on Figure 1 shall be zoned SRP Overlay.

\subsection{Energy Resources}

\subsubsection{Goal:}

Explore large-scale renewable energy production to supplement the County's sources of power. 


\subsubsection{Program:}

As grant funds become available, the Planning Division will develop a program to identify potential sites for large-scale solar energy production within the area, and work with the California Energy Commission and local utility companies to explore potential investment in this field. 


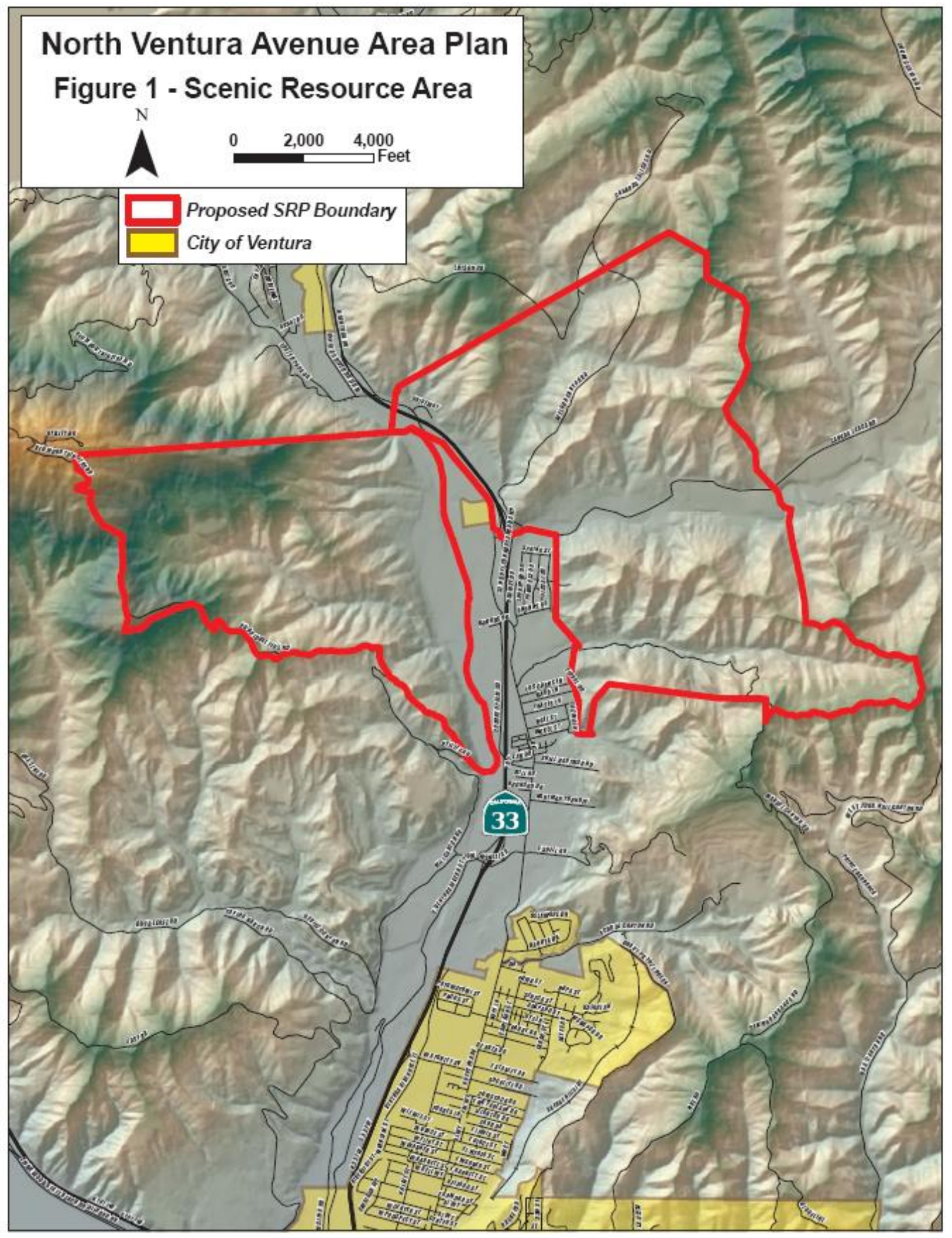




\section{Hazards}

Goals, policies, and programs of the countywide Goals, Policies and Programs will continue to be applied to the North Ventura Avenue area and are supplemented by the following goals, policies:

\subsection{Flood Hazards and Drainage}

\subsubsection{Goal:}

Use best available technology to prevent any increase in surface water runoff consistent with the standards of the Regional Water Quality Control Board.

\subsubsection{Policy:}

All discretionary development shall result in no net increase of runoff.

\subsubsection{Program:}

The Planning Division will use grant funds to prepare and process an amendment to Parking and Landscaping standards of the Non-Coastal Zoning Ordinance consistent with the above goals.

\subsection{Hazardous Materials and Waste}

\subsubsection{Goal:}

Minimize exposure to hazardous substances

\subsubsection{Program:}

Ventura County Planning Division, in conjunction with Environmental Health Division, will prepare a budget proposal or grant application to develop a plan to cleanup Brownfield sites within the area. 


\section{Land Use}

Goals, policies, and programs of the countywide Goals, Policies and Programs will continue to be applied to the North Ventura Avenue area and are supplemented by the following goals, policies:

\subsection{General Goals, Policies and Programs}

\subsubsection{Goals:}

1. Ensure new development follows appropriate sustainable urban form through New Urbanist design principles.

2. Provide a balance of industry, commerce, recreation and housing to be integrated at pedestrian scale in order to encourage a sound economic base and afford opportunities to live, work, shop and play within the community, while minimizing vehicle miles traveled.

3. Encourage the revitalization and rehabilitation of all Brownfield areas, particularly the former USA Petroleum site, in the North Ventura Avenue area.

4. Encourage the development of strategically-located shared parking areas to be used by multiple land use contained within a quarter-mile radius of the parking area.

5. Locate and design all commercial, industrial, urban residential and mixed-use zoned land to minimize vehicle miles traveled between other surrounding uses.

6. Locate and design commercial, industrial, urban residential and mixed-use zoned land so as to minimize land use incompatibility with surrounding land uses, as much as is practical.

7. To establish a mixed-use specific plan land use category to encourage the development of mixed-use projects.

\subsubsection{Policies:}

1. All discretionary development shall be located in conformance with the Land Use Map and Zoning Compatibility Matrix (Figures 3.1 and 3.2).

\subsubsection{Programs:}

1. The Planning Division will prepare a work program or grant application for consideration by the Board of Supervisors to develop and adopt a New Urbanist form-based development code that emphasizes pedestrian and bike orientation, integration of land uses, treatment of streetscapes as community living space, and environmentally sensitive building design and operation. This program should include a ministerial development approval process for new mixed-use development projects

2. Concurrent with the General Plan Amendment for North Ventura Avenue Areas Plan, land currently designated as 'Industrial', under the existing Area Plan, will be re-zoned by the County to SP (Specific Plan) zone.

3. The Planning Division will prepare a work program or grant application for consideration by the Board of Supervisors to revise and adopt new parking standards in the County Zoning Ordinance to facilitate shared motor vehicle parking spaces at the neighborhood level and not parcel-byparcel.

\subsection{Open Space}

\subsubsection{Goals:}

1. Guide growth into Existing Community areas, and discourage the conversion of open space and agricultural land to urban land uses.

2. Increase minimum parcel size standards so as to protect scenic and other resources. 


\subsubsection{Policies:}

1. All land located outside of the Existing Community as depicted on the Land Use Map (Figure3.1) shall be designated Open Space

2. The minimum parcel size of new parcels in the Open Space designation shall be 80 acres.

\subsection{Residential Single-Family}

\subsubsection{Goal:}

Preserve existing single-family neighborhoods.

\subsubsection{Policy:}

All residential single-family parcels shall be located in conformance with the Land Use Map and Zoning Compatibility Matrix (Figures 3.1 and 3.2).

\subsection{Residential Multi-Family}

\subsubsection{Goal:}

Encourage higher density housing to provide more balance of housing options within North Ventura Avenue.

\subsubsection{Policy:}

All residential multi-family units shall be located in conformance with the Land Use Map (within MixedUse Specific Plan and Residential Multi-Family zones) and the Zoning Compatibility Matrix (Figures 3.1 and 3.2).

\subsection{Mixed-Use Specific Plan}

\subsubsection{Goals:}

1. Create pedestrian-oriented, self contained, and sustainable urban villages that will serve as areas for mixed-use developments consisting of medium and high density residential, retail, service commercial, office, industrial, entertainment, community facilities and institutions, and open space uses within Specific Plan zoned land.

2. Encourage higher intensity, transit-supportive and pedestrian/bicycle-oriented development within urban villages while retaining compatibility with nearby land uses.

3. Permit mixed-use developments on existing and future land zoned commercial, industrial and Specific Plan.

4 Create visually attractive connections/transitions between land uses.

5. Streamline the development review process for mixed-use developments.

\subsubsection{Policies:}

1. Permit a wide range of retail, service commercial and personal service uses; financial institutions and services; business, professional and medical offices; industrial, entertainment, recreation and other community facilities; and medium and high density residential uses within all areas designated as commercial, industrial and Specific Plan (SP) zones.

2. A range of development intensities and building heights shall be permitted within commercial, industrial and Specific Plan zones.

3. The design and development of buildings within urban villages shall be oriented to the street and transit services; and safe and convenient access shall be provided for pedestrians and bicyclists between buildings and transit stops, parking areas and other facilities. 
4. Provide well landscaped pedestrian and bicycle linkages between public and private lands within urban villages.

5. All mixed-use specific plan parcels shall be located in conformance with the Land Use Map and the Zoning Compatibility Matrix (Figures 3.1 and 3.2).

\subsection{Commercial}

\subsubsection{Goals:}

1. Encourage commercial uses which will provide the shopping, service, and entertainment needs of residents and workers in the area.

2. Allow for utilization of the Commercial Business District (CBD) overlay zone within the Commercial designated area along Ventura Avenue to allow more flexibility of development standards and design.

\subsubsection{Policies:}

1. All commercial units shall be located in conformance with the Land Use Map (within Mixed-Use Specific Plan and Commercial zones) and the Zoning Compatibility Matrix (Figures 3.1 and 3.2).

\subsubsection{Program:}

The Planning Division will prepare a budgetary proposal to study the appropriateness of rezoning the Commercial designated area along Ventura Avenue with the Commercial Business District (CBD) overlay zone.

\subsection{Industrial}

\subsubsection{Goals:}

1. Preserve existing industrial uses.

2. Encourage the presence of green-technology industrial activity in the North Ventura Avenue area.

\subsubsection{Policy:}

\subsubsection{Program:}

Ventura County Planning Division will seek grant funds to develop a program to identify potential sites suitable for renewable energy production and manufacturing facilities, while working with the California Energy Commission and local utility companies to explore and attract potential investment in this field.

\subsection{Oil Field Industrial}

\subsubsection{Goal:}

1. Preserve existing oil field industrial uses.

2. Encourage the presence of green-technology industrial activity in the North Ventura Avenue area.

\subsubsection{Policy:}

Oil Field Industrial land shall be located in conformance with the Land Use Map (Figure 3.1).

\subsubsection{Program:}

Ventura County Planning Division will seek grant funds to develop a program to identify potential sites suitable for renewable energy production and manufacturing facilities, while working with the California Energy Commission and local utility companies to explore and attract potential investment in this field. 
Figure 3.1

North Ventura Avenue Area Plan

Existing Community Land Use Map
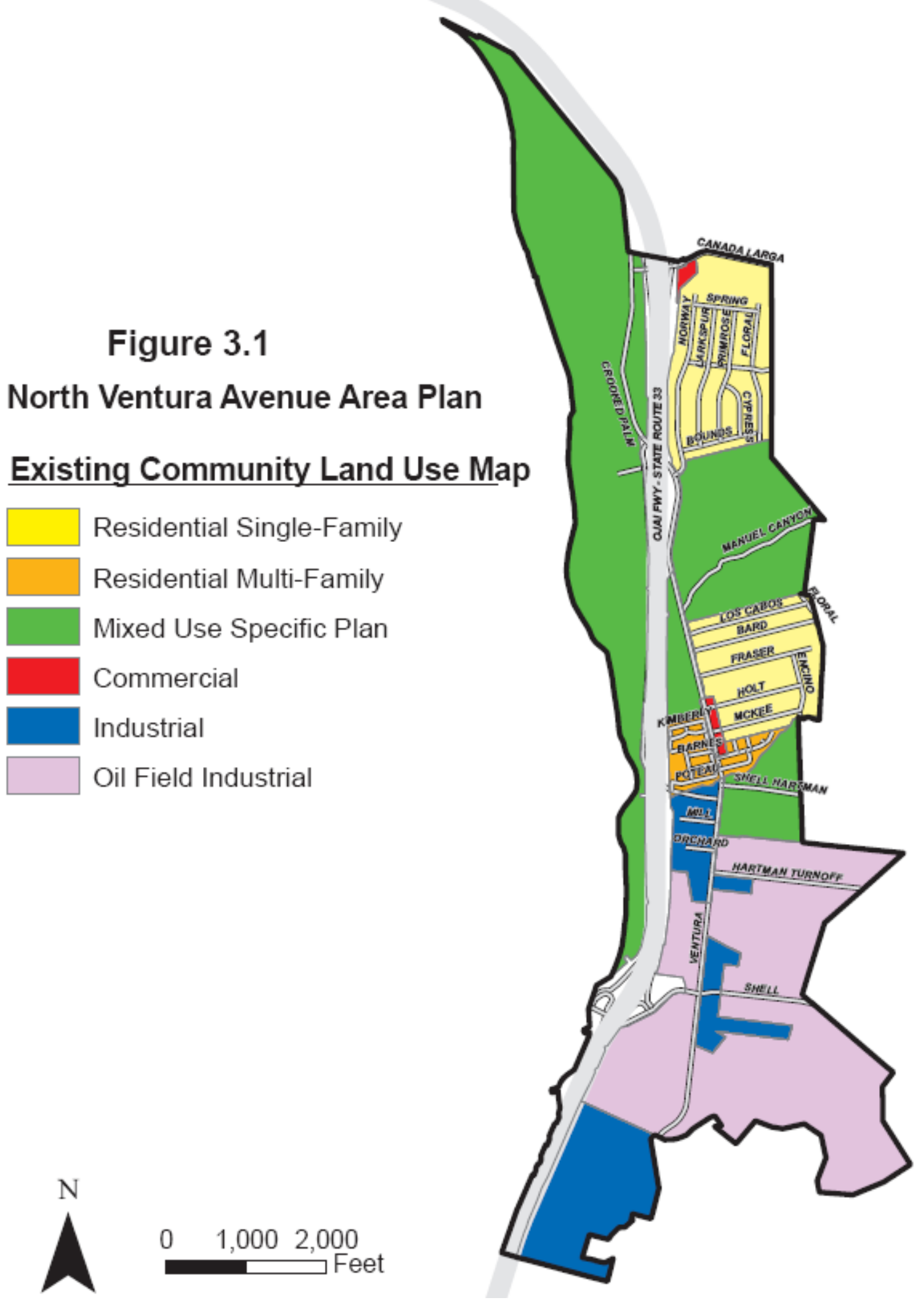
Figure 3.2

Zoning Compatibility Matrix (County)

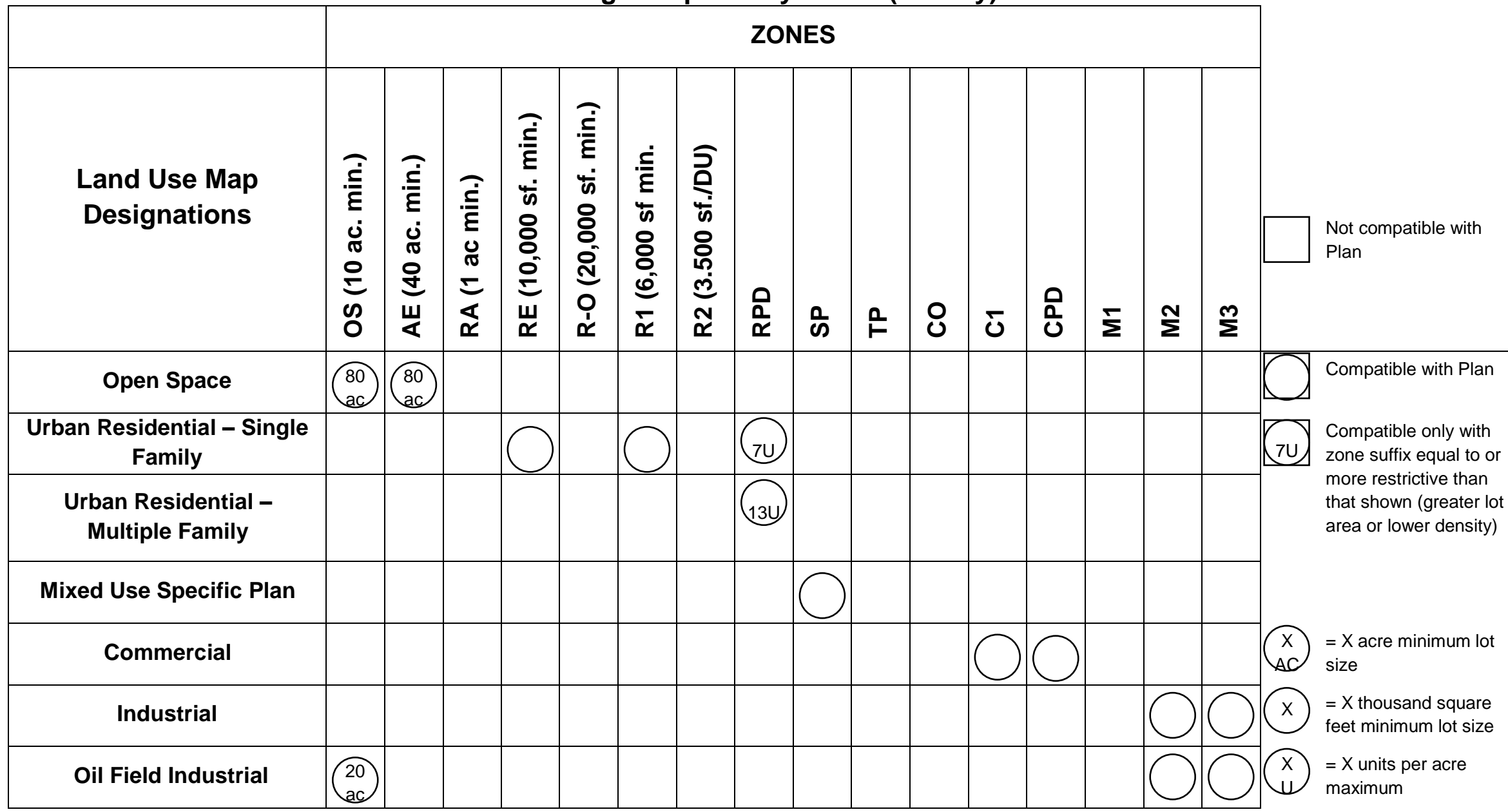


Figure 3.3

Building Intensity/Population Density Standards

\begin{tabular}{|c|c|c|c|c|c|c|c|c|c|}
\hline \multicolumn{10}{|c|}{ Open Space } \\
\hline Designation & Acres & $\begin{array}{c}\text { Max. BIdg. Coverage } \\
\text { (\% Of Lot Area) }\end{array}$ & $\begin{array}{c}\text { Maximum } \\
\text { Intensity } \\
(\mathrm{DU} / \mathrm{AC})^{*}\end{array}$ & DUs & \multicolumn{2}{|c|}{$\begin{array}{l}\text { Average } \\
\text { Pop/DU }\end{array}$} & \multicolumn{2}{|c|}{ Population } & $\begin{array}{c}\text { Average Pop. } \\
\text { Density (Pop/Acre) }\end{array}$ \\
\hline Open Space & 6,742 & $5 \%$ & $1 \mathrm{DU} / 80 \mathrm{ac}$ & 84 & \multicolumn{2}{|c|}{2.34} & & 197 & .03 \\
\hline \multicolumn{10}{|c|}{ Residential } \\
\hline Designation & Acres & $\begin{array}{c}\text { Max. Bldg. Coverage } \\
\text { (\% Of Lot Area) }\end{array}$ & $\begin{array}{l}\text { Maximum } \\
\text { Intensity } \\
\text { (DU/AC) }\end{array}$ & DUs & \multicolumn{2}{|c|}{$\begin{array}{l}\text { Average } \\
\text { Pop/DU }\end{array}$} & \multicolumn{2}{|c|}{ Population } & $\begin{array}{c}\text { Average Pop. } \\
\text { Density (Pop/Acre) }\end{array}$ \\
\hline Single Family & 121 & $44 \%$ & 7.00 & 847 & \multicolumn{2}{|c|}{2.34} & & 1,982 & 16.97 \\
\hline Multi Family & 17 & $55 \%$ & 13.00 & 221 & \multicolumn{2}{|c|}{2.34} & & 517 & 30.41 \\
\hline \multicolumn{10}{|c|}{ Mixed Use } \\
\hline Designation & Acres & $\begin{array}{c}\text { Max. Bldg. Coverage } \\
\text { (\% Of Lot Area) }\end{array}$ & DUs & \multicolumn{2}{|c|}{ Population } & & $\begin{array}{l}\text { cted } \\
\text { Area } \\
\text { SF) }\end{array}$ & \multicolumn{2}{|r|}{ Employees } \\
\hline $\begin{array}{c}\text { Mixed Use Specific } \\
\text { Plan }\end{array}$ & 139 & $60 \%$ & 2,780 & \multicolumn{2}{|c|}{6,505} & \multicolumn{2}{|c|}{2,085} & \multicolumn{2}{|r|}{4,170} \\
\hline \multicolumn{10}{|c|}{ Commercial/Industrial } \\
\hline Designation & Acres & $\begin{array}{c}\text { Max. Bldg. Coverage } \\
\text { (\% Of Lot Area) }\end{array}$ & $\begin{array}{l}\text { Projected } \\
\text { Floor Area } \\
\text { (x1000 SF) }\end{array}$ & $\begin{array}{r}\text { Aver } \\
\text { Employees }\end{array}$ & $00 \mathrm{SF}$ & & yees & Aver & ge Employees/Acre \\
\hline Commercial & 4 & $60 \%$ & 26.136 & 2. & & & 52 & & 13 \\
\hline Industrial & 69 & $40 \%$ & 601.128 & 2. & & & 1202 & & 17 \\
\hline Oil Field Industrial & 176 & $20 \%$ & 766.656 & 2. & & & 1533 & & 8 \\
\hline
\end{tabular}

*Excludes second dwelling units per Section 65852.2 of the State Government Code. ** 2000 Census

Methodology:

- $\quad$ Mixed Use Specific Plan assumes: 20 dwelling units/acre; 2.34 persons/dwelling unit; 1.5 employees/dwelling unit; and 1000 square feet/employee

- Projected Floor Area calculated as \% of total acreage built on for Commercial (15\%), Industrial (20\%) and Oil Field Industrial (10\%) 


\section{Public Facilities and Services}

Goals, policies, and programs of the countywide Goals, Policies and Programs will continue to be applied to the North Ventura Avenue area and are supplemented by the following:

\subsection{Transportation and Circulation}

\subsubsection{Goals:}

1. Provide safe pedestrian and bicycle pathways throughout the community to connect housing with services, entertainment, employment, and recreation.

2. Acquire sufficient public right-of-way for bicycle and pedestrian access.

3. Discourage on-street parking along Ventura Avenue.

4. Promote public transit and increase ridership within the North Ventura Avenue area.

\subsubsection{Policy:}

1. All public streets, bike paths/lanes shall be designed and constructed in accordance with the standards depicted in Figure 4.1.

2. All street improvements shall be in accordance with the cross sections depicted in Figure 4.2.

\subsubsection{Programs:}

1. The Planning Division will seek grant funds to develop a program with the Ventura County Transportation Commission and Gold Coast Transit to provide more information to riders at transit stops, libraries, lodging, and event facilities.

2. The Planning Division will prepare a work program for consideration by the Board of Supervisors to add class II bikeways along both sides of Ventura Avenue, to replace existing on-street parking.

3. The Planning Division will prepare and adopt a work program for consideration by the Board of Supervisors to make all sidewalks along Ventura Avenue complete and continuous, on both sides of the street, to replace existing on-street parking provision along the right-of-way

\subsection{Fire Protection}

\subsubsection{Goal:}

Optimize firefighting and emergency response capabilities consistent with the City of Ventura's EIR (2005, p. 4.11-32).

\subsubsection{Program:}

Ventura County Fire Protection District will prepare plans to construct a new fire station in the North Avenue area as determined necessary by the Ventura County Fire Chief. 
Figure 4.1

North Ventura Avenue Area Plan

\section{Circulation Map}

$\square$ Existing Community Boundary

ROADS

= Freeway/Highway

$\longmapsto$ Urban Arterial

- $=$ Collector

\section{BIKE PATHS}

=-. - Class I

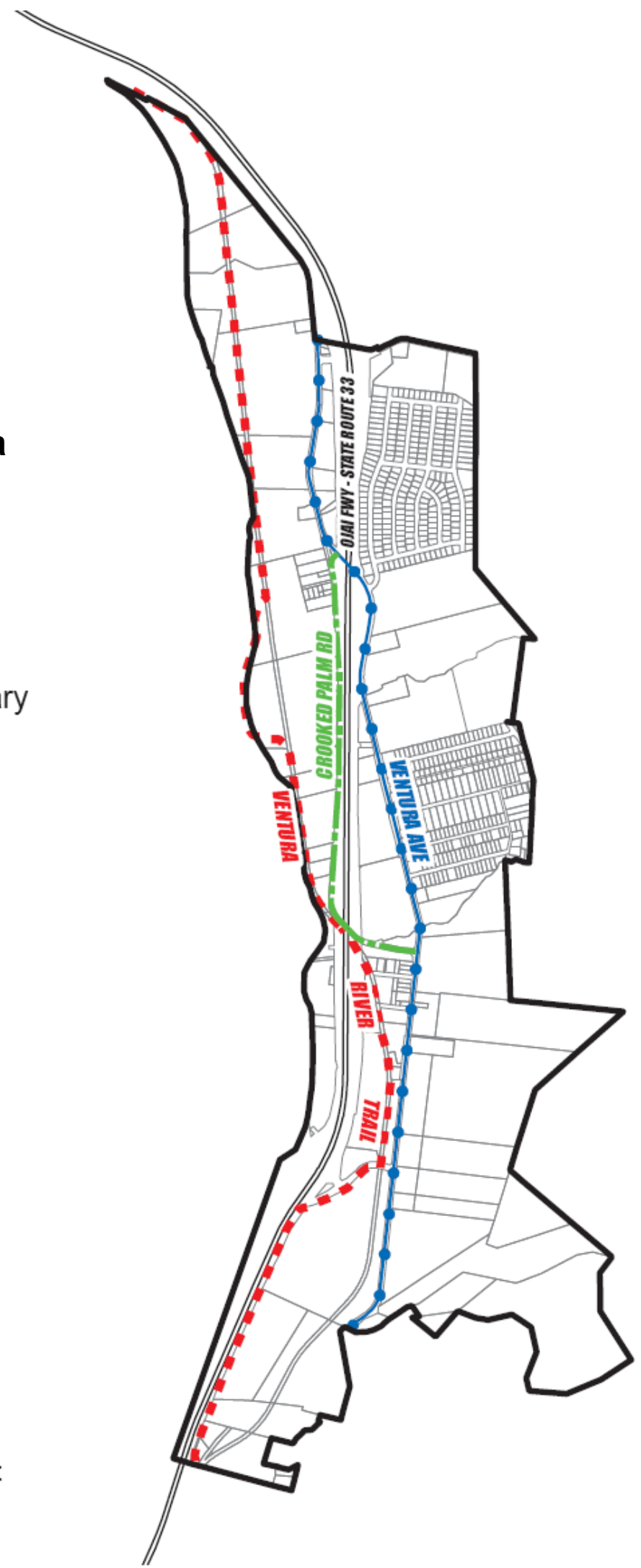


Figure 4.2

Street Cross-Sections

Urban Arterial - North Ventura Avenue

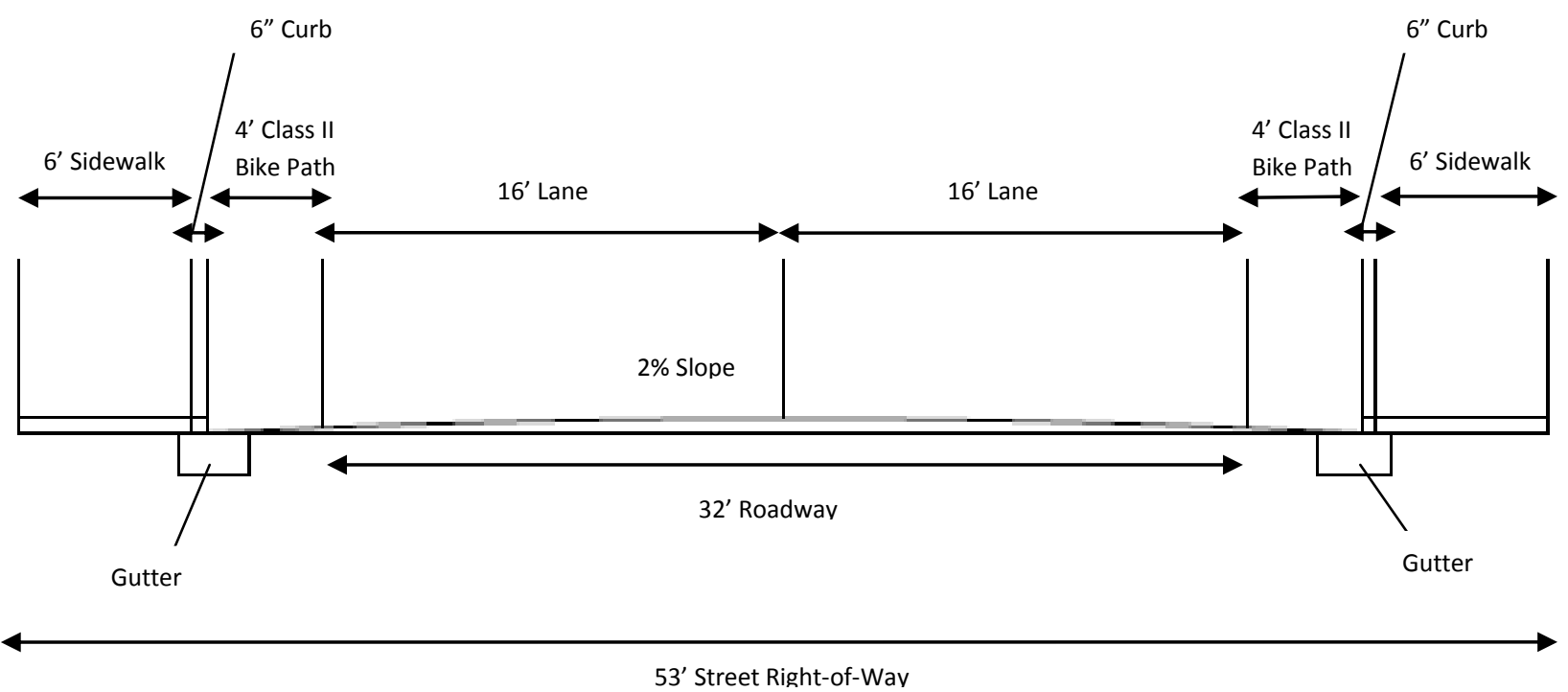

Collector - Crooked Palm Road

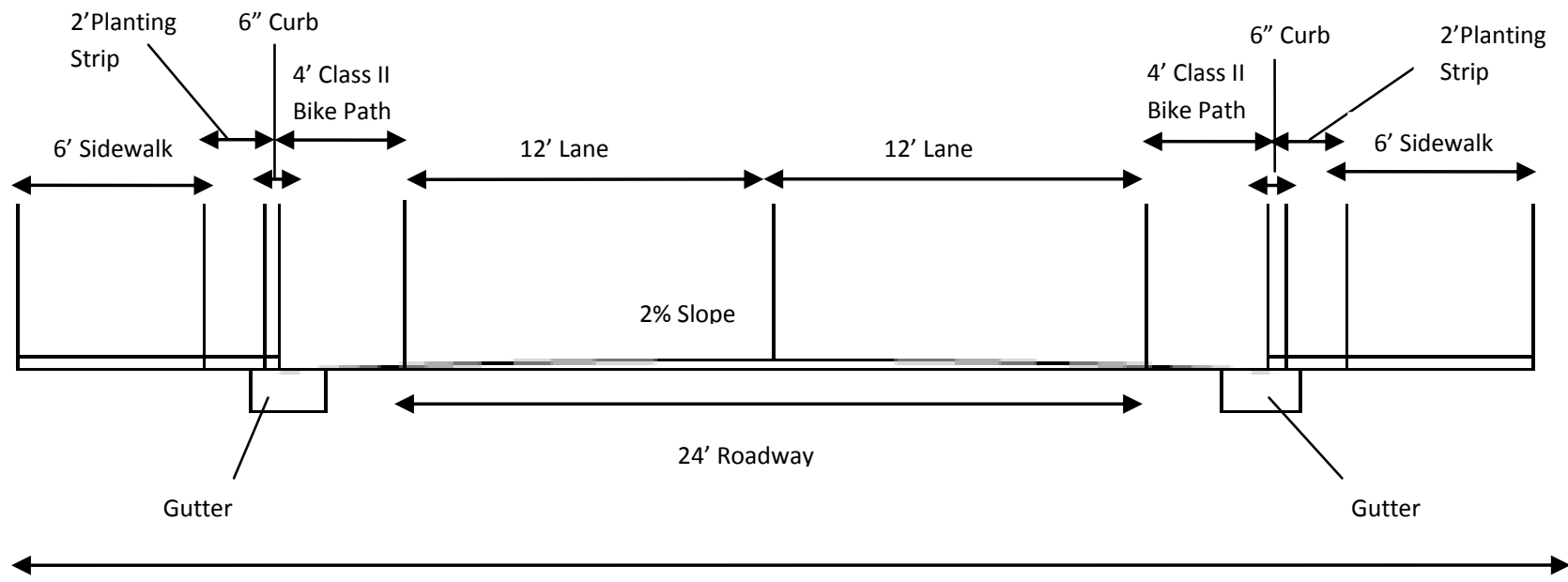

49' Street Right-of-Way 


\section{Glossary}

Unless the context requires otherwise, the definitions of words and terms provided in this section, as well as the countywide Goals, Policies and Programs of the County General Plan, shall be used in interpreting this Plan.

Brownfield: the term 'brownfield site' means real property, the expansion, redevelopment, or reuse of which may be complicated by the presence or potential presence of a hazardous substance, pollutant, or contaminant.

Development: the subdivision of land; construction or alteration of structures, roads, utilities, and other facilities; installation of septic systems; grading activities; depositing of refuse; disposal of any material; dredging or mineral extraction, debris or fill materials; and the clearing of natural vegetation with the exception of agricultural activities. Routine repair and maintenance activities are not included.

Green-Technology: companies engaged in this technology use a continuously evolving group of methods, materials and techniques for generating renewable forms of energy, non-toxic cleaning products, and waste/pollution reduction products. The term includes research and development in this field.

Mixed-Use: lands where employment, shopping and residential land uses will be developed and integrated in a compact urban form, at higher development intensities, with pedestrian-oriented and highly accessible by public transit. These areas will foster community interaction by providing a focus on community facilities.

Mixed-Use Developments: a development consisting of one or more lots developed as a cohesive project and designed with a blend of various compatible uses such as commercial, residential and institutional. The uses are typically located within one building, but for larger projects the uses often span separate buildings located within the same project site.

New Urbanist Design Principles: primarily seek to create compact, walkable, mixed-use neighborhoods which place importance on green architecture, energy conservation, historic preservation and accessibility. Typically these resemble old European villages, with a discernible center within five minutes walk of all residential units.

New Urbanist Form-Based Development Code: a development approval process that uses simple and clear graphic prescriptions and parameters for height, siting, and building elements to address the basic necessities for forming good public space, in accordance with New Urbanist design principles. The code includes regulating plans, required building lines, parking setbacks, building envelope standards, architectural standards, and streetscape standards.

No Net Increase of Runoff: water from rain or irrigation that flows over the land surface is fully absorbed into the ground.

Right-of-Way: the area of land (including roads and sidewalks) over which people and goods have the right to pass or travel

Urban Villages: sites with a concentration of mixed land uses and mixed-use developments, a high level of self containment (people working, recreating and living in the same area), reduced car reliance, an emphasis on cycling, walking and transit use, and strong community institutions and interaction. 